\title{
MANAJEMEN PERENCANAAN PROGRAM BAHASA ARAB DI MAYANTARA SCHOOL MALANG
}

\author{
Varda Himmatul Aliyah \\ humanioravarda@gmail.com \\ Ahmad ‘Ali Maghfur \\ ibrahimmaghfur@gmail.com \\ Danial Hilmi \\ danialhilmi@gmail.com
}

Universitas Islam Negeri Maulana Malik Ibrahim Malang

Jalan Gajayana 50 Malang

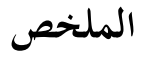

عديد من المؤسسات التعليمية غير الرممية اليوم التي تعمل في بحال اللغات الأجنبية ويجب أن تنظر في المزايا والفرص والتحديات في التخطيط لها. ظهور هذه المؤسسات على الأمل لتوفير فوائد للأشخاص الذين يرغبون في استكشاف اللغات الأجنبية، على الرغم أنه لم يتم تدريس بعضها في المدرسة. وبين العديد من المؤسسات، بالطبع لديها تخطيط برامج لغتها الخاصة، بما في ذلك Mayantara School Malang . سيتم مناقشة هذه الأشياء في الدراسة، خاصة تتعلق ببرنامج اللغة العربية. نوع البحث المستخدم هو البحث الكيفي في

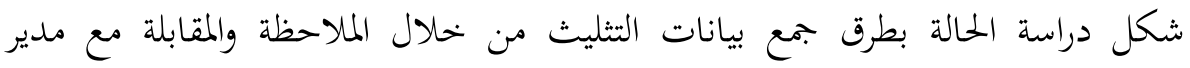
Mayantara School Malang يكون هذا البحث مادة مرجعية ومادية لأصحاب المؤسسات التعليمية والمعلمين لتخطيط

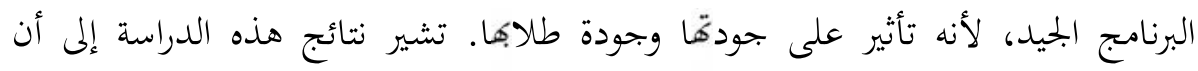
Mayantara School Malang وقادرة على قراءة الفرص اللازمة لتلبية الاحتياجات المستقبلية.
\end{abstract}

الكلمات المفتاحية: التخطيط، برامج اللغة العربية، Mayantara School 


\begin{abstract}
Abstrak
Dewasa ini, banyak bermunculan lembaga pendidikan non-formal yang bergerak dalam bidang bahasa Asing yang pasti telah mempertimbangkan adanya keuntungan, peluang dan tantangan dalam perencanaannya. Kemunculan lembaga-lembaga ini dengan harapan mampu memberikan manfaat bagi orang yang ingin menjelajahi bahasa asing, meskipun tidak sedikit bahasa asing telah diajarkan di sekolah. Dari sekian banyak lembaga, tentunya memiliki perencanaan program bahasanya sendiri, termasuk Mayantara School Malang. Hal tersebut yang akan dibahas dalam penelitian ini khususnya hal yang berkaitan dengan program bahasa Arab. Jenis penelitian yang digunakan adalah penelitian kualitatif yang berbentuk studi kasus dengan metode pengumpulan data triangulasi melalui pengamatan dan wawancara kepada manajer Mayantara School Malang. Penelitian ini diharapkan dapat menjadi bahan pertimbangan dan bahan referensi bagi pemilik lembaga dan pendidik untuk merencanakan perencanaan program yang baik, karena dapat berdampak pada kualitas institusi dan siswa. Hasil penelitian ini menunjukkan bahwa Mayantara School Malang adalah lembaga yang baik dalam perencanaan program bahasa asing dan mampu membaca peluang yang dibutuhkan untuk keperluan masa depan.
\end{abstract}

Kata kunci: Perencanaan, Program Bahasa Arab, Mayantara School

\title{
PENDAHULUAN
}

Kebutuhan manusia akan sebuah pendidikan tidak bisa dipungkiri, dan pendidikan yang bagus dan ideal yang akan mampu menarik hati khalayak umum. Pendidikan adalah suatu proses merubah manusia menjadi lebih baik, lebih mahir dan terampil. (Komariah, 2018: 107) Sehingga banyak orang yang berlomba-lomba membuat sebuah lembaga yang menarik dengan ciri has masing masing. Hadirnya berbagai organisasi dalam kehidupan manusia merupakan salah satu fenomena kehidupan modern untuk membantu dan memudahkan pemenuhan kebutuhan hidup secara individu maupun masyarakat. (Jannah, 2013: 122)

Salah satu pendidikan non-formal yang diminati oleh khalayak umum adalah sebuah lembaga kursus bahasa. Karena kebutuhan manusia akan bahasa sungguh tak terelakkan. Lebih lebih akan bahasa asing, yang seolah-olah sudah menjadi bagian dari hidup generasi sekarang atau generasi milenial. 
Para peserta memilih lembaga tersebut tentunya tidak asal asalan mereka punya pertimbangan sendiri, salah satunya adalah pertimbangan perencanaan program yang ada di lembaga non-formal tersebut. Sebab sebuah perencanaan dalam sebuah program bahasa tidak akan bisa ditingalkan laksana daging yang tidak akan meningalkan tulangnya. Oleh karena itu jika program tersebut ingin berjalan dengan lancar maka harus ada sebuah perencanaan. Sebab suatu kegiatan atau program tidak lepas dari adanya manajemen. (Ardi, 2019: 21).

Dari beberapa lembaga yang ada, terpilih Mayantara School Malang sebagai lembaga yang akan diteliti. Mayantara School merupakan salah satu lembaga pendidikan non-formal, yang bergerak dalam program bahasa asing mulai dari bahasa Jerman, Inggris, Mandarin, Korea, Jepang dan bahasa Arab. Sedangkan lokasinya berada di Jalan Puncak Mandala 40A, Raya Tidar, Malang, lembaga ini sudah disahkan oleh Dinas Pendidikan kota Malang dan memiliki ijin operasional lembaga krsus No.421.8/8005/35.73.307/2014. Hal ini menunjukkan bahwa lembaga ini adalah lembaga yang sudah diakui oleh dinas pendidikan, yang tentunya Mayantara School berpeluang memiliki kualitas yang bagus.

Urgensi mengkaji perencanaan program bahasa Arab di Mayantara School Malang, diharapkan bisa dijadikan sebagai bahan pertimbangan untuk bagi para pemilik lembaga non-formal yang bergerak di bidang program bahasa. Terkait langkah-langkah yang dilakukan dalam perencanaan program bahasa, karena sebuah perencanaan program dapat mempengaruhi kualitas peserta didik di lembaga tersebut. Selain itu, dengan mengetahui perencanaan program di Mayantara school Malang diharapkan bisa menjadi barometer awal bagi kalangan yang ingin membuat lembaga yang serupa.

Adapun penelitian yang pernah mengkaji tentang manajemen penididkan non-formal adalah penelitian milik Alvi Dyah Rahmawati dengan judul "Manajemen Pengorganisasian Program Kursus Bahasa Arab di Pare Kediri”. (Rahmawati, 2018 : 52) Hasil dari penelitian tersebut yaitu bahwa manajemen pengorganisasian yang 
dimiliki lembaga kursus bahasa Arab Al-Azhar masih lemah karena beberapa kendala seperti, manajer lembaga kursus bahasa Arab Al-Azhar belum memiliki struktur organisasi yang jelas karena hanya memberikan pembagian tugas secara lisan kepada setiap anggota dan tidak membuat bagan struktur organisasi untuk anggota sehingga membuat kedudukan antara bawahan dan atasan tidak terlihat. Sehingga sistem pengorganisasiannya kurang tertata rapi.

Letak perbedaan penelitian tersebut dengan pembahasan penulis yaitu mengenai fungsi manajemen dan lembaga yang diteliti. Lembaga non-formal yang diteliti dalam penelitian ini cenderung kepada fungsi perencanaan manajemen di Mayantara School dan berfokus pada analisis SWOT, penyusunan visi dan misi dan proses perencanaan program Bahasa Arab itu sendiri. Dan secara umum, belum pernah ada yang membahas ini sebelumnya.

Jenis penelitian yang digunakan dalam penelitian ini adalah penelitian kualitatif dengan pendekatan studi kasus. Bogdan dan Taylor menyatakan bahwa pendekatan kualitatif adalah penelitian yang dapat memperoleh data tertulis maupun lisan dalam proses pengamatan secara mendalam terhadap objek penelitian. (Moleong, 2007: 3) Jadi, penelitian kualitatif itu bersifat deskriptif dan lebih cenderung mencari sebuah hipotesis baru dari data yang diperoleh.

Penelitian ini bertujuan untuk mengetahui secara mendalam tentang perencanaan program bahasa di Mayantara School Malang. Peneliti menggolongkan dalam penelitian studi kasus karena memusatkan pada suatu yang unik secara mendalam dan rinci. Sumber data dalam penelitian ini adalah manajer dari Mayantara School Malang yang bernama Ratih Putri dan selanjutnya akan disebut dengan inisial RP sebagai informan kunci terkait dengan perencanaan program bahasa di Mayantara School Malang.

Sedangkan, instrumen pengumpulan data yang digunakan adalah wawancara mendalam, observasi dan dokumentasi. Wawancara yang dilakukan dengan sumber 
utama, observasi yang langsung dilakukan oleh peneliti di lapangan yakni di Mayantara School dan data dokumen yang didapatkan yaitu berupa dokumen yang berkaitan dengan lembaga. Data yang telah diperoleh akan dianalisis menggunakan proses anlisis data Miles dan Huberman yang terdiri dari reduksi data, penyajian data dan verifikasi dan setelahnya peneliti akan menarik kesimpulan.

\section{PEMBAHASAN}

\section{Analisis SWOT}

Sebuah manajemen yang baik pasti memiliki perencanaan yang baik pula. Tanpa sebuah perencanaan, seorang manajer tidak bisa mengetahui resiko-resiko dan tantangan-tangtangan yang mungkin dihadapi dikemudian hari. Pada dasarnya sebuah perencanaan atau planning merupakan tahapan kegiatan yang masuk akal dan terstruktur yang bertujuan untuk menetapkan keputusan, kegiatan, dan langkahlangkah yang akan dilalui supaya tujuan bisa dicapai dengan efektif dan efesien (Mulyono, 2008: 25). Jadi, dalam sebuah perencanaan harus memakai pemetaan yang tepat sehingga tujuan dibentuknya sebuah program bisa ditindaklanjuti dengan maksimal agar tujuan yang diinginkan bisa tercapai.

Oleh karena itu, dalam fungsi perencanaan akan ditemui beberapa langkah sebagai berikut (Mulyono, 2008: 26) : (a) menggapai ke depan untuk memperkirakan keadaan dan kebutuhan masa depan. (b) menentukan tujuan yang akan dicapai. (c) Menentukan kebijakan yang ditempuh terkait tujuan yang telah ditetapkan sebelumnya. (d) menentukan sebuah program, yang mencakup pendekatan yang ditempuh, jenis dan urutan kegiatan. (e) memperkirakan biaya yang merupakan pikiran jumlah biaya yang diperlukan. (f) menentukan jadwal dan prosedur kerja yang ditempuh.

Seorang manajer harus memikirkan dengan matang mengenai tujuan/sasaran atau visi berdasarkan logika, bukan perasaan. Selain itu, manajer harus mempertimbangkan hal-hal atau kemungkinan yang akan terjadi, inilah yang 
dinamakan analisis SWOT, analis ini mencakup kekuatan, kelemahan, peluang dan tantangan. Dengan mempertimbangkan hal tersebut, diharapkan sebuah program bisa berjalan dengan baik, dan tujuan yang telah dibuat bisa tercapai dengan maksimal.

Proses perencanaan program bahasa di lembaga kursus Mayantara School melakukan analisis SWOT. Sebagaimana hasil wawancara dengan RP pada tanggal 1 April 2019 (Putri, 2019) bahwa Mayantara school memiliki kekuatan yaitu para tenaga pengajar dengan kualifikasi minimal S-1 sesuai dengan bidang yang diampunya dalam hal ini adalah para pengajar bahasa Arab, bahasa Jerman, bahasa Inggris, bahasa Mandarin dan bahasa-bahasa yang lainnya. Selain kekuatan pengajarnya, mereka juga memiliki managemen yang bagus dalam administrasi dan publikasi. Seperti yang dituturkan RP bahwa publikasi yang dilakukan oleh lembaga tersebut melalui jejaring sosial, seperti website dan instagram. Sedangkan publikasi offline juga dilakukan yakni dengan cara mengadakan seminar ke beberapa kampus yang ada di kota Malang, dan juga dengan mendatangi sekolah-sekolah yang membutuhkan kursus tambahan terkait pendalaman bahasa. Biasanya hal ini mereka lakukan saat menjelang libur semester.

Meskipun lembaga ini memiliki sebuah kekuatan, di sisi yang lain juga ada kelemahan. Seperti yang dituturkan oleh RP (Putri, 2019) bahwa kelemahan dari lembaga tersebut adalah belum memiliki tempat tetap (masih menyewa). meski menyewa tetapi ruang pembelajaran sudah sangat baik, yang terdiri dari tiga lantai dan sebelas ruangan dengan fasilitas yang lengkap. Maksimal kelas hanya diisi oleh empat orang pelajar. Kendati demikian perihal belum memiliki gedung yang tetap menjadi sebuah kekurangan yang ada di Mayantara School.

Sebagaimana hasil wawancara bersama RP pada tangal 1 April 2019 (Putri, 2019) menuturkan bahwa saat Mayantara berdiri, program kursus bahasa Jerman adalah program yang digagas pertama. Sebab, pada saat itu di kota Malang belum ada lembaga kursus yang membuka program bahasa Jerman. Dalam hal ini, Mayantara School berpeluang besar untuk membuka program tersebut. karena 
banyak sekali pelajar yang membutuhkan kemampuan bahasa Jerman untuk melanjutkan impian berkuliah ke Eropa.

Dari penuturan diatas bisa disimpulkan bahwa peluang pertama dari Mayantara School adalah akan kebutuhan pelajar yang ingin mempelajari bahasa Jerman. Hal ini tentunya menjadi sebuah peluang yang menarik direspon oleh pihak Mayantara sendiri pada kala itu. Lambat laun program bahasa yang ada di Mayantara School selalu bertambah seiring dengan bertambahanya kebutuhan dan peluang yang ada di masyarakat.

Begitu pula dengan program bahasa Arab yang sudah ada di lembaga tersebut. Munculnya program ini didasari atas kebutuhan beberapa pelajar yang ingin mendalami bahasa Arab. Seperti yang dituturkan melalui wawancara (Putri, 2019), bahwa program bahasa Arab adalah program baru di Mayantara School yang langsung mendapat respons positif dari peminatnya. Peminat program ini tidak hanya dari kalangan siswa yang masih bersekolah atau mahasiswa yang masih berkuliah, tetapi juga para pekerja bahkan orang lanjut usia.

Sekarang program bahasa Arab sudah ada 4 kelas yang terdiri dari sebagian pelajar dari jenjang sekolah menengah pertama dan sekolah menengah atas. Dengan tiga level: 1) Kelas dasar (mubtadi'), 2) menengah (mutawasith), 3) atas (mutaqoddim). Sedangankan buku acuan yang dipakai adalah Durus al-lughah dan arbiyah baina yadaik.

Sesunguhnya segala hal tak akan lepas dari tantangan yang menunggu di depan. Mayantara School, sebagaimana hasil wawancara bersama RP pada tangal 1 April 2019 (Putri, 2019), menunturkan bahwa tantangan dari lembaga ini adalah bermunculannya lembaga kursus yang lain, baik yang berskala kecil atau berskala besar. Kendati demikian, pihak Mayantara senantiasa optimis dan terus berusaha untuk memberikan pelayanan yang optimal kepada para pelanggan. Tentunya juga melakukan pengembangan-pengembangan lanjutan. 


\section{Penyusunan Visi dan Misi Lembaga}

Setelah melakukan analisis SWOT, langkah selanjutnya yakni menentukan sebuah tujuan dan target yang ingin dicapai oleh sebuah lembaga. Sebab, apa artinya sebuah lembaga tanpa adanya tujuan dan target. Kedua hal tersebut merupakan fungsi dari sebuah prencanaan atau tahthith itu sendiri. seperti yang dinyatakan oleh Benowitz (Amtu, 2011: 38) bahwa tujuan dilakukannya perencanaan yaitu untuk menawarkan suatu tujuan terbentuknya organisasi, yang mana tujuan dan hasil menjadi fokus utama, memberikan sebuah landasan bagi kerja tim, menjadi langkah penangulangan atas permasalahan dan perubahan yang akan muncul secara tak terduga-duga.

Oleh karena itu visi dari sebuh lembaga adalah sesuatu yang sangat fundamental. Visi merupakan sebuah gagasan atau ide yang dituangkan berdasarkan kondisi lembaga yang dikelola untuk mencapai tujuan yang diingikan. (Alifiyah, Imron, Juharyanto, 2019: 36). Visi yang tepat akan berimpilikasi bagi kemaslahatan lembaga tersebut. Seperti pendapat Komariyah dan Triatna (2010: 81) bahwa dengan visi maka semangat akan bangkit kembali, meningkatkan dan menumbuhkan kinerja, terwujudnya prestasi pendidikan, serta membuat kemandirian berfikir dan bertindak.

Sebagaimana hasil dari dokumentasi yang telah dilakukan peneliti bahwa visi Mayantara school adalah memberikan layanan pendidikan dan pelatihan kepada masyarakat agar dapat memiliki kemampuan dan ketrampilan yang berguna bagi pengembangan potensi diri.

Visi dari Mayantara School tersebut sudah sangat tepat mulai dari pengambilan kata yang lugas, singkat, mudah dimengerti dan berorientasi pada masa depan. Seperti dituturkan oleh Edwin A. Locke (Ismail, 2005: 4-5) yang menyatakan bahwa ciri khas dalam menyusun sebuah visi adalah mengunakan kalimat yang ringkas, sederhana, jelas, mudah dimengerti, disukai oleh khalayak umum, dan

orientasinya adalah masa depan. Oleh karena itu, pembuatan visi juga harus 
memperhatikan dua kemampuan: 1) kemampuan mengamati sebuah perubahan di masa mendatang dari sesi trennya. 2) kemampuan mengambarkan perubahan yang akan dibuat di masa tersebut.

Tahapan selanjutnya setelah terbentuk sebuah visi, maka visi tersebut akan dikembangkan dalam beberapa misi. Misi adalah sebuah pilihan atau jalan yang dipilih (the chosen track) oleh lembaga atau organisasi pendidikan bagi pelajarnya atau masyarakatnya. (Mulyono, 2008: 120) Merumuskan misi berarti membuat sebuah gambaran tentang peta perjalanan yang akan ditempuh. Dengan membuat sebuah peta yang akurat menggambarkan dunia yang akan dimasuki, akan tercipta sebuah kesempatan bagi lembaga atau organisasi tersebut dalam mengelola dan memenuhi kebutuhan lingkungannya sehingga perkembangan dan kelangsungan hidup lembaga tersebut akan terjamin.

Merumuskan sebuah misi harus didasarkan pada lima macam pertanyaan berikut: (1) Bagaimana asumsi terhadap lingkungan yang akan dilayani? (2) Keperluan apa saja yang akan dipenuhi? (3) Siapa saja peserta yang ingin akan digarap? (4) Jenis, jenjang dan model lembaga apa yang akan dikelola? (5) Apa hal terbaik yang bisa dilakukan dalam rangka mengolah lembaga tersebut? (Mulyono, 2008: 123). Jika ingin membut misi yang tepat maka kelima pertanyaan tersebut yang harus terjawab.

Sebagaimana hasil dari dokumentasi yang telah dilakukan peneliti bahwa untuk mewujudkan visinya, dirumuskanlah empat misi sebagaimana berikut: 1) mendidik dan melatih peserta kursus dengan bekal ketrampilan agar kompeten di bidang keahliannya, 2) meningkatkan mutu tenaga pengajar agar tetap profesional dan handal, 3) menyediakan fasilitas media pembelajaran yang terstandar dan aplikatif, 4) mengadakan kursus maupun pelatihan ketrampilan secara online agar mudah dijangkau masyarakat. Misi yang baik adalah misi yang sesuai dengan visinya dan keempat misi tesebut, sudah sesuai dengan visi yang dicanangkan oleh Mayantara School dan juga sesuai dengan tren yang ada di masa kini. 


\section{Pembentukan Program Bahasa Arab di Mayantara School}

Ketika sebuah visi dan misi telah terbentuk, maka proses selanjutnya adalah mencanangkan program-program yang mendukung terwujudnya visi. Mayantara School merupakan lembaga kursus yang bertolak pada bidang kebahasaan. Jadi, program yang dibuat adalah program bahasa. Ada beberapa bahasa yang bisa ditemukan di Mayantara School diantaranya: bahasa Jerman (Deutsch), Belanda (Dutch), Perancis, Inggris, Jepang, Korea dan Arab. Seperti yang telah dibahas sebelumnya bahwasannya bahasa Jerman adalah program bahasa yang pertama kali diwujudkan di Mayantara School dan dilanjutkan dengan bahasa-bahasa yang lainnya termasuk bahasa Arab.

Program bahasa Arab sendiri adalah program yang baru di Mayantara School. Program ini muncul sejak 2018. Meski program ini baru muncul, tetapi daya minatnya tidak bisa dianggap rendah. Seperti yang telah dijelaskan sebelumnya bahwa program bahasa arab sudah ada 4 kelas yang terdiri dari kalangan siswa yang masih bersekolah, mahasiswa yang masih berkuliah, dan para pekerja bahkan orang lanjut usia.

Dalam pembentukan program ini, banyak hal yang harus dilakukan oleh para staff dan pengajar diantaranya adalah menemukan para calon pengajar bahasa Arab yang berkualifikasi, seperti hasil wawancara bersama RP (Putri, 2019) yang menyatakan bahwa Mayantara School memilih calon pengajar yang sudah berkualifikasi minimal S1 dengan bukti ijazah dan memiliki kompetensi mengajar yang diukur dengan tes Microteaching. Selain menentukan kualifikasi dari para calon pengajar, juga dilakukan pemilihan buku ajar yang akan digunakan berdasarkan masukan dari para pengajar bahasa.

Saat merencanakan sebuah program, tidak akan lepas dari jumlah biaya yang dibutuhkan. Hal ini selaras dengan salah satu tahapan perencanaan, yaitu : berorientasi masa depan untuk bisa memperkirakan kebutuhan apa saja yang harus 
dipenuhi di kemudian hari. Dan menentukan biaya yan meliputi perkiraan jumlah biaya yang diperlukan dalam sebuah lembaga. (Mulyono, 2008: 26)

Sebagaimana hasil wawancara bersama RP pada tangal 1 April 2019 (Putri, 2019) yang menuturkan bahwa di Mayantara School sendiri dilaksanakan perkiraan pengeluaran biaya dalam berbagai hal, diantaranya biaya sewa gedung, sarana dan prasarana pendidikan yang dibutuhkan, banyaknya modul yang akan digunakan, gaji pengajar dan biaya pemasaran baik dalam bentuk seminar, brosur dan promosi online. Semua rincian biaya harus jelas sehingga tidak terjadi hal yang tidak diinginkan di masa yang akan datang.

Selanjutnya adalah langkah terakhir dalam perencanaan yaitu menentukan jadwal dan prosedur kerja yang ditempuh. Hal ini sesuai dengan salah satu fungsi dari sebuah perencanaan. yaitu menentukan jadwal dan prosedur kerja yang ditempuh. (Mulyono, 2008: 26) Sebagaimana hasil wawancara bersama RP pada tangal 1 April 2019 (Putri, 2019) yang menuturkan bahwa pelaksanaan pembelajaran dan pelatihan Mayantara School dilaksanakan di sebuah gedung yang terletak di Jalan Puncak Mandala 40A, Raya Tidar, Malang. Waktu pelaksanaan program dimulai hari Senin s/d Minggu. Jadi tidak ada hari libur kecuali libur nasional dan hari Besar. Dengan jam kerja mulai pukul 07.30-20.30 WIB. Begitu pula dengan program bahasa Arab, yang rata-rata sehari guru diberi beban 5-6 jam pelajaran dengan durasi waktu yang terpisah-pisah. Contoh : pagi dua jam, siang dua jam, dan sore dua jam.

Adapun berdasarkan hasil observasi langsung yang dilakukan peneliti di Mayantara School bahwa pembelajaran dilaksanak dalam kelas kecil yang berisi maksimal empat orang. Gedung mayantara terdiri dari tiga lantai dengan sebelas ruangan lengkap dengan fasilitas seperti: papan tulis, audio, proyektor dan lain sebagainya. 
Sebagaimana hasil wawancara bersama RP pada 1 April 2019 (Putri, 2019) yang menuturkan bahwa selain pembelajaran dipusatkan dalam gedung Mayantara, mereka juga menyediakan tenaga untuk ekstrakurikuler bahasa Inggris di sekolah yang membutuhkan dengan jumlah maksimal siswa adalah dua puluh lima siswa, jika lebih dari batas maksimal maka akan dibagi menjadi dua kelas. Program ini merupakan bagian dari pemanjaan pelanggan yang dilakukan oleh lembaga tersebut. Dan hal ini biasanya dilakukaan menjelang libur sekolah tiba. Mayantara School juga menyediakan pelatihan untuk para karyawan yang hendak mendalami bahasa. Yang mana untuk kelas karyawan biasanya perkelasnya diisi sekitar sepuluh orang.

Dalam sebuah proses perencanaan juga perlu dirumuskan rencana berjangka, seperti: program jangka pendek, jangka menengah dan jangka panjang. Hal ini selaras dengan apa yang diungkapkan oleh (Fattah, 2006: 59-60) merumuskan rencana jangka pendek, menengah dan jangka panjang sangat diperlukan dalam sebuah perencanaan. Sebagaimana hasil wawancara bersama RP pada tangal 1 April 2019 (Putri, 2019) peneliti mendapatkan informasi tiga jenis rencana berjangka dari Mayantara School. Adapun rencana jangka pendek yang ingin dicapai adalah perbaikan modul khususnya untuk program bahasa Arab. Karena program ini merupakan program yang baru digagas pada tahun 2018, dan sementara waktu mereka memakai dua modul buku yakni: Durus al-lughah dan arbiyah baina yadaik.

Dan rencana jangka menengah yaitu dengan mewujudkan kelas online yang lebih efektif. Sudah ada kelas online tetapi masih membutuhkan pengefektifan. Sebab diera industri 4.0 pembelajaran online dirasa perlu di kembangkan dan ini merupakan pasar yang harus dijamah oleh Mayantara School.

Di samping dua rencana berjangka diatas, mereka juga memiliki rencana jangka panjang. Membuka cabang baru di berbagai tempat di Indonesia, adalah rencana jangka panjang lembaga ini, dan RP (Putri, 2019) menuturkan bahwa sekarang Mayantara School sudah memiliki cabang di Bali. Dengan terbukanya 
sebuah cabang baru, Mayantara telah memberikan sebuah bukti konkret dalam hal output yang dihasilkan.

Jadi, berdasarkan keterangan dan berbagai informasi yang didapatkan, perencanaan mengandung arti: pertama, seorang manajer memikirkan dengan matang terlebih dahulu sasaran dan tindakan berdasarkan pada beberapametode, rencana atau logika dan bukan perasaan. kedua, rencana mengarahkan tujuan organisasi dan menetapkan prosedurterbaik untuk mencapainya. ketiga, rencana merupakan pedoman untuk: organisasi memperoleh dan menggunakan sumber daya yang diperlukan untuk mencapai tujuan, anggotaorganisasi melaksanakan aktivitas yang konsisten dengan tujuan dan proseduryang sudah ditetapkan, dan memonitor dan mengukur kemajuan untukmencapai tujuan, sehingga tindakan korektif dapat diambil bila kemajuan belum memuaskan. Dan ini telah dilaksanakan dalam manajemen perencanaan di Mayantara School Malang.

\section{SIMPULAN}

Pada dasarnya segala sesuatu yang sistematis dalam berbagai bidang kehidupan manusia itu tidak luput dari sebuah proses perencanaan termasuk bidang pendidikan. Dan suatu perencanaan yang baik itu hendaklah mengandung unsur orientasi masa depan (future oriented) dengan tujuan menghadapi dan mengatasi permasalahan yang akan terjadi di masa yang akan datang. Salah satu hal yang perlu diperhatikan saat ini adalah bidang bahasa, sehingga banyak lembaga-lembaga terbentuk bersiap menghadapi tantangan tersebut yang salah satunya berbentuk lembaga kursus seperti Mayantara School Malang.

Proses perencanaan dilakukan dengan beberapa tahapan yaitu analisis SWOT, pembentukan visi dan misi serta penentuan program yang akan dicanangkan untuk mewujudkan visi tersebut. Setelah dilakukan penelitian di Mayantara School Malang, dapat dihasilkan beberapa temuan, sebagai berikut; 1. Langkah-langkah yang sudah di lakukan Mayantara School perencanaan program bahasa sudah berdasarkan kepada analisis SWOT (Strengths, Weaknesses, Opportunities, Threats) yang 
dilanjutkan dengan menentukan tujuan dan target/sasaran yang dituju oleh Mayantara School; 2. Perencanaan sebuah program tentunya akan akan berafiliasi dalam sebuah Visi, dan visi lembaga ini sudah sangat sesuai dengan misi yang ada serta realitas dan telaah dari analisis SWOT; 3. Program yang terbentuk yang salah satunya adalah program bahasa Arab di Mayantara School Malang sudah sesuai dengan visi lembaga.Dapat disimpulkan bahwa Mayantara School Malang telah melakukan proses perencanaan yang baik, sehingga bisa dijadikan sebagai referensi bagi para calon pembentuk lembaga terkait. 


\section{DAFTAR PUSTAKA}

Alifiyah, I. Imron, A. Juharyanto 2019. Kepemimpinan Visioner Kepala Sekolah dalam Mengembangkan Karakter Peserta Didik. Jurnal Administrasi dan Manajemen Pendidikan. 2(1): 32-39.

Amtu, Onisimus. 2011. Manajemen Pendidikan di Era Otonomi Daerah. Bandung: ALFABETA.

Ardi, Nuri Shabrina Putri. 2019. Manajemen Pembinaan Akhlak Dalam Penguatan Pendidikan Karakter Peserta Didik. Jurnal Administrasi dan Manajemen Pendidikan. 2(1): 17-25.

Fattah, Nanang. 2006. Landasan Manajemen Pendidikan. Bandung: PT. Remaja Rosdakarya

Ismail. 2005. Makalah Visi dan Misi Depag. Surabaya: Balai Diklat Pegawai Teknis Keagamaan Surabaya.

Jannah, Raudhatul Jannah. 2013. Karakterisik dan Spektrum Manajemen Pendidikan Islam. Al-Fikrah: Jurnal Kependidikan Islam IAIN Sulthan Thaha Saifuddin. 122-131

Komariah, A. \& Triatna, C. 2010. Visionary Leadership (Menuju Sekolah Efektif). Jakarta: Bumi Aksara.

Komariah, Nur. 2018. Implementasi Fungsi Manajemen Pendidikan di SDI Wirausaha Indonesia. Perspektif. 16(1): 107-112.

Moleong, Lexy J. 2014. Metodologi Penenelitian Kualitatif. Bandung: PT. Remaja Rosdakarya

Mulyono, M. A. 2008. Manajemen Administrasi dan Organisasi Pendidikan. Jogjakarta: Ar-Ruzz Media.

Rahmawati, Alvi Dyah. 2018. Manajemen Pengorganisasian Program Kursus Bahasa Arab di Pare Kediri. Arabi: Journal of Arabic Studies. 3 (1), 52-60. 